\title{
WR geochemistry of the deformed peridotite xenoliths from kimberlite pipe Udachnaya and their bearing in kimberlite petrogenesis
}

\author{
A.M. Agashev ${ }^{1}$, Yu.V. Cherepanova ${ }^{1}$, N.P. Pokhilenko ${ }^{1}$ \\ ${ }^{1}$ Institute of Geology and Mineralogy SB RAS, Novosibirsk, Russia. (agashev@uiggm.nsc.ru)
}

A suite of 22 xenoliths of deformed (sheared) garnet lherzolites were studied for their WR major and trace elements geochemistry, mineralogy and mineral composition. The broad objective of this project is to investigate composition and evolution of the deepest layer of lithospheric mantle and its bearing in kimberlite petrogenesis. Those xenoliths carried up to the surface by kimberlites of Udachnaya pipe. They are typical four phase lherzolites consisting of olivine, orthopyroxene, clinopyroxene and garnet in variable amounts. Typically, they have a porphyroclastic textures composed by bigger grains of major phases that setting in matrix of fine-grained sugar-like olivine. Porphyric grains often make up the chains in which garnets usually have an isometric shape, but clinopyroxene and olivine often deformed and elongated along the chains direction. All xenoliths are unique fresh with no signs of secondary alteration, many of them being analyzed for major elements composition show loss of ignition of around zero. All of them are big enough (weight 400 grams and more) and suitable for WR analysis.

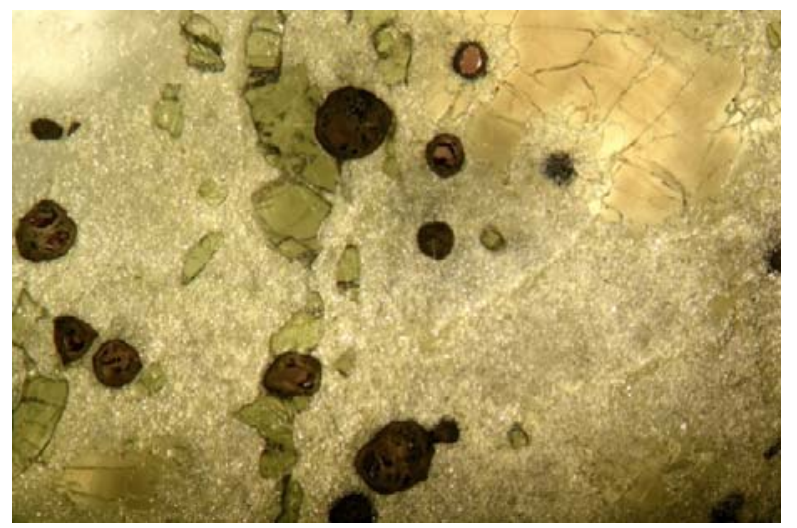

Fig. 1 Microphotograph of sample Uv-208/02

The samples were cut and only middle part of xenoliths without any surface which was in touch with kimberlite was taken for study. All analyses were performed at the Institute of Geology and Mineralogy SB RAS. Major elements were analyzed by RFA method and for the trace elements solution ICP-MS method have been used. Major elements composition of minerals was analyzed using electron microprobe.

\section{P-T estimates}

The P-T conditions of equilibrium were calculated from chemical composition of garnet and two pyroxenes using Brey and Kohler (1990) equations. The most of xenoliths have calculated equilibrium temperature in the range of $1300-1400{ }^{\circ} \mathrm{C}$ and pressure of 60-70 Kbar. The similar results were obtained previously in (Boyd et al, 1997) for the partly serpentinized xenoliths of same type. Deformed peridotites represent a deepest layer of lithospheric mantle and most probably the boundary layer between stable lithospheric mantle and convecting asthenosphere.

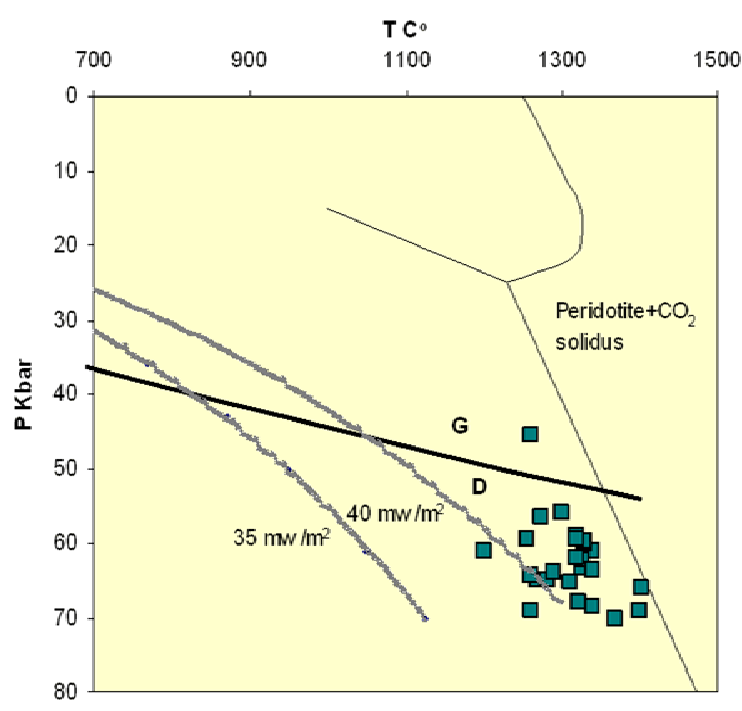

Fig. 2 P-T diagram for the deformed peridotite xenoliths from Udachnaya kimberlite. The continental geotherms of 35 and $40 \mathrm{mw} / \mathrm{m}^{2}$ (Pollack and Chapman 1977), graphite/diamond transition line and solidus of carbonated peridotite are shown.

\section{Major elements}

On the major elements composition deformed peridotites xenoliths are depleted in most of the elements, but enriched in $\mathrm{MgO}$ comparative to primitive mantle (PM) composition of McDonough and Sun (1995). On the variation diagrams of $\mathrm{CaO}, \mathrm{TiO}_{2}$ and $\mathrm{Al}_{2} \mathrm{O}_{3}$ concentrations with that of $\mathrm{MgO}$, deformed 
peridotites are located between PM and cratonic Harburgite compositions (McDonough and Rudnick 1998 ) indicating their residual nature. $\mathrm{K}_{2} \mathrm{O}$ and $\mathrm{P}_{2} \mathrm{O}_{5}$ behave independently from other elements and often enriched over PM composition.

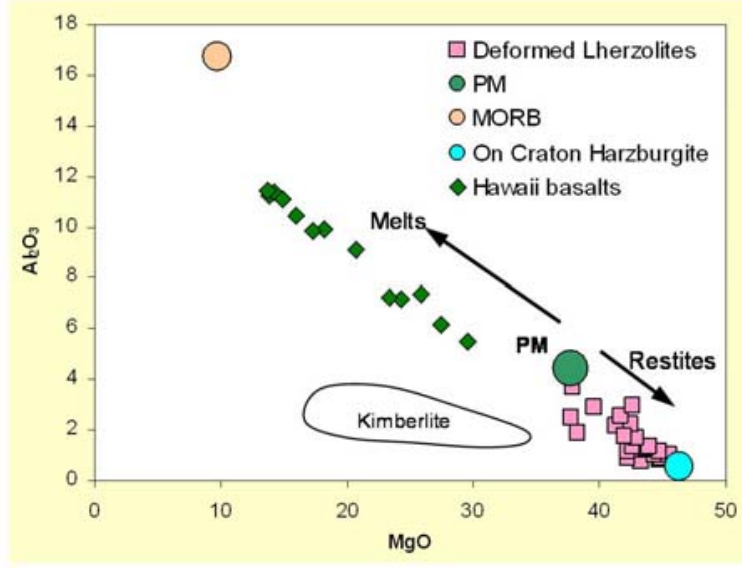

Fig. $3 \mathrm{MgO}-\mathrm{Al}_{2} \mathrm{O}_{3}$ variation diagram for the deformed peridotite xenoliths from Udachnaya kimberlite.

\section{Trace elements}

Bulk -rock trace elements composition of deformed peridotites are enriched in the hardly incompatible element. The degree of enrichment in particular elements is variable being 10 times over PM composition for $\mathrm{K}$ and $\mathrm{Rb}$ and 2-5 times for $\mathrm{Ba}$, Th, $\mathrm{U}$, $\mathrm{Nb}$ and $\mathrm{La}$. The concentration of elements of middle incompatibility (MREE, Zr, and Hf) varies around PM model composition and even slightly depleted.

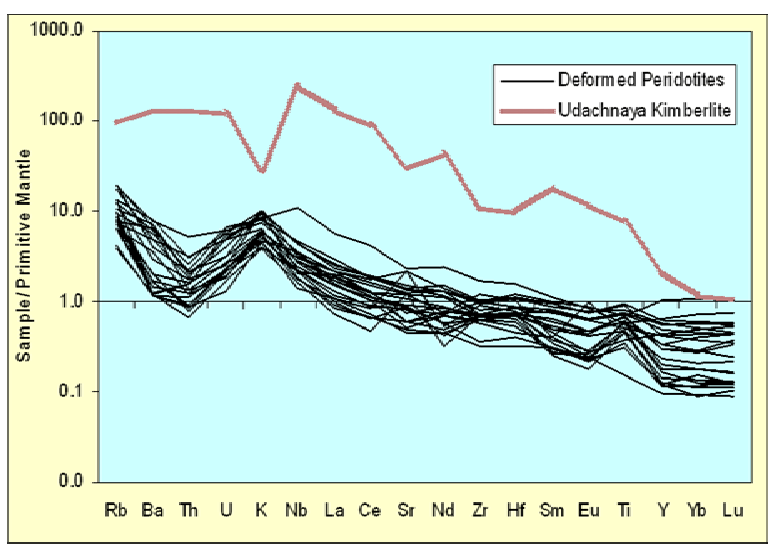

Fig 4. Primitive mantle normalized trace elements patterns of deformed peridotites in comparison with that of their host kimberlite of Udachnaya pipe.

Heavy REE and Y concentrations are lower than in the PM model indicating a residual nature of deformed peridotites. Normalized to PM trace elements patterns (Fig. 4) of deformed peridotites have a positive and negative peaks that is opposite to kimberlite composition. Therefore, significant contamination by host kimberlite can be excluded. Major residence phase for $\mathrm{K}$ and $\mathrm{Rb}$ is a kelyphitic rims around the garnets. Other incompatible elements are resided mostly in clinopyroxene and garnet and some part of incompatible elements balance are attributed to micron-size metasomatic phases located along the grain boundaries of rock-forming minerals.

\section{Geochemical evolution model}

Based on the xenoliths chemical composition a simplified model of their geochemical evolution has been proposed and sown in Fig 5. At the first stage the depleted residues after high degree of melt extraction from the PM-like source have been formed. Probably, this process occurred in Archaen time as indicated by Re-depletion ages of deformed peridotite xenoliths reported in Pearson et al (1995). Lately, originally depleted rocks were enriched in incompatible elements via metasomatic processes. The second stage of geochemical evolution is attributed to cryptic metasomatism and manifested in enrichment of rocks in hardly incompatible elements. The most appropriate agent was incompatible elements enriched melt of carbonatite affinity. Second metasomatic event (evolution stage 3a, Fig 5.) led to changes in modal mineralogy of peridotites, growth of garnet and clinopyroxene moves bulk-rocks chemistry toward PM composition. The chemistry of samples correlates well with increasing of modal amount of Grt+Cpx in rocks mineralogy and do not agrees with any admixture of kimberlite melt. Trace elements composition of samples that develops the trend (3b, Fig. 5) controlled by micron-size metasomatic phases located along the grain boundaries and could be produced by interaction with residual liquid and fluids after fractional crystallization in stage $3 \mathrm{a}$.

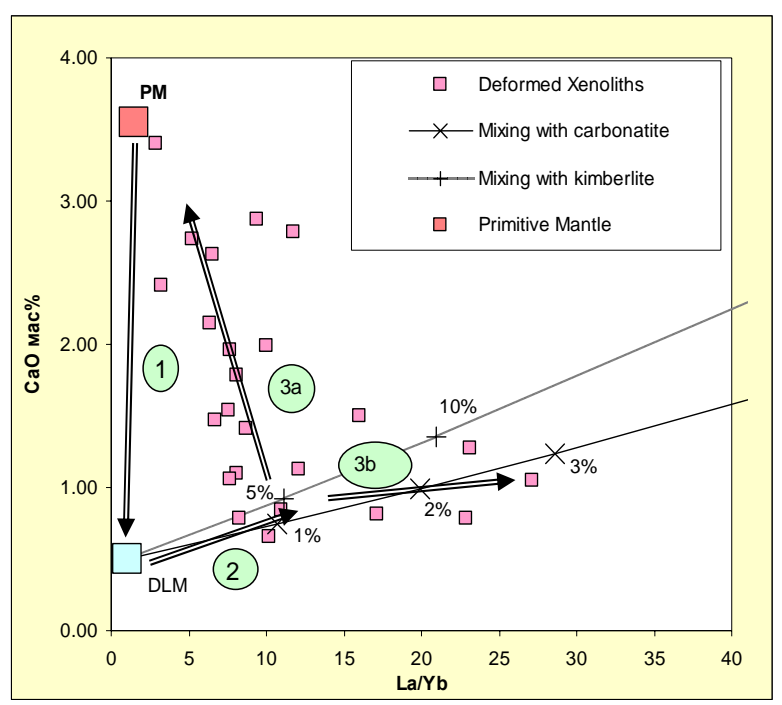

Fig. 5 Schematic model of the geochemical evolution of deformed peridotites.

Stage 1. Initial depletion (see description in the text). Stage 2. Metasomatic enrichment by the interaction with incompatible elements enriched melt of carbonatite affinity. Stage 3.a). Modal metasomatism by silicate (kimberlite) melt. Growth of garnet and 
clinopyroxene moves bulk-rocks chemistry toward PM composition. b) Metasomatic enrichment by residual liquid and fluids after fractional crystallization in stage 3a. DLM is a hypothetical Depleted Lithosperic Mantle composition where $\mathrm{Al}_{2} \mathrm{O}_{3}$ concentration was adopted from on-craton harzburgite composition of (McDonough and Rudnick 1998).

\section{Partial melting}

Geochemical character of kimberlites requires the source to be depleted in major elements and heavy REEs, but enriched in hardly incompatible elements. The WR composition of deformed peridotite xenoliths fulfills those conditions. Calculations of partial melting using both, major and trace elements and average composition of the studied samples closely reproduce composition of Udachnaya pipe kimberlites. Therefore the deformed peridotites of lithospheric mantle roots could be a suitable source for kimberlite melts.
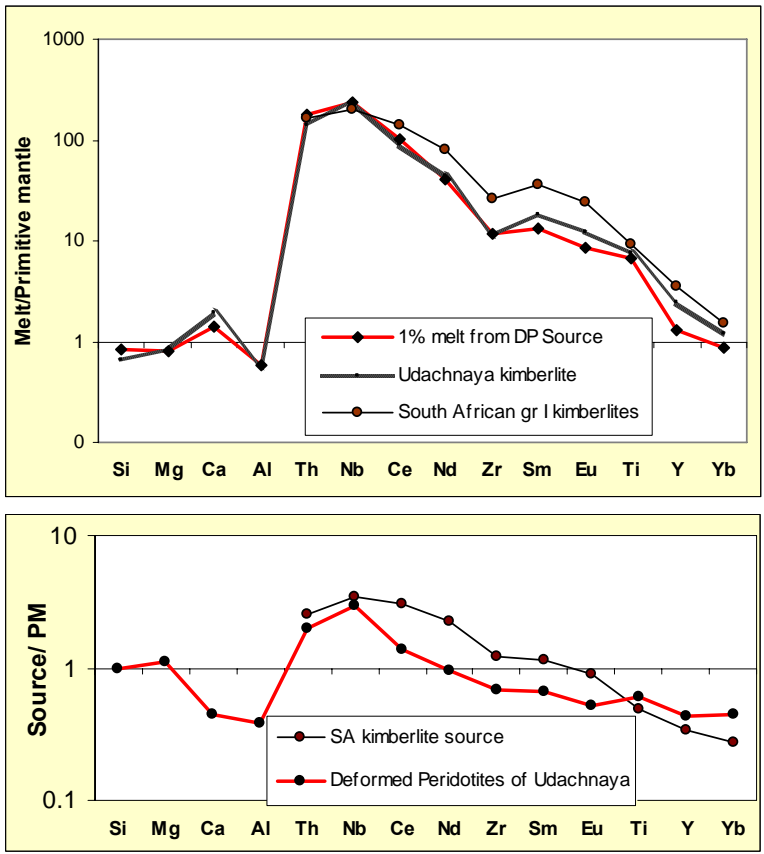

Fig. 6 Upper plot: Primitive mantle normalized composition of $1 \%$ partial melt of deformed peridotite xenoliths average composition (DP source) compared to Udachnaya pipe kimberlites and South African group I kimberlites (Le Roex et al, 2003) composition. Lower plot: Composition of deformed peridotites of Udachnaya compared to calculated source composition (Le Roex et al, 2003) for South African kimberlites.

This work was partly supported by a RFBR grant № 08-05-00751.

\section{References}

Boyd, F.R., Pokhilenko, N.P., Pearson, D.G., et al. 1997. Composition of the Siberian cratonic mantle: evidence from Udachnaya peridotite xenoliths. Contribution to Mineralogy and Petrology 128,
228-246.

Brey, G.P., Kohler, T., 1990. Geotermobarometry in fourphase lherzolites. II. New thermobarometers and practical thermobarometers. Journal of Petrology 31, 1353-1378.

Le Roex, A.P., Bell, D. R., Devis, P., 2003. Petrogenesis of group I kimberlites from Kimberley, South Africa: Evidence from bulkrock geochemistry. Journal of Petrology 44, 2261-2286.

McDonough, W.F., Sun, S.-s., 1995. The composition of the Earth. Chemical Geology 120, 223-253.

McDonough, W.F., Rudnick, R.L., 1998. Mineralogy and composition of the upper mantle. In Hemley, R. J. Ultrahigh-Pressure mineralogy, Reviews in mineralogy 37, Mineralogical Soc. of America, Washington, 138-164.

Pollack, H.N., Chapman, D.S., 1977. On the regional variation of heat flow, geotherms and lithosphere thickness. Tectonophysics 38, 279-296.

Appendix table 1 .

Major elements composition of Deformed Peridotite xenoliths from kimberlite pipe Udachnaya

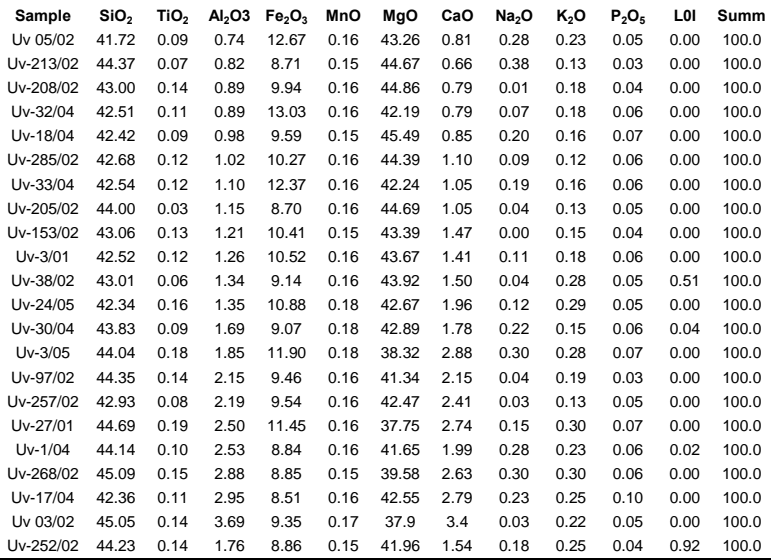

